\title{
Reduced Diversity and Complexity in the Leaf-Litter Ant Assemblage of Colombian Coffee Plantations
}

\author{
INGE ARMBRECHT,${ }^{*} \dagger \S$ LEONARDO RIVERA, ${ }^{*}$ AND IVETTE PERFECTO $\dagger$ \\ *Universidad del Valle, Departamento de Biología, Apartado Aéreo 25360, Cali, Colombia \\ †School of Natural Resources and the Environment, University of Michigan, 430 East University, Ann Arbor, MI 48109, U.S.A.
}

\begin{abstract}
Coffee agroecosystems have recently undergone a dramatic intensification in Colombia, a megadiverse country, especially in terms of the nature of shade cover. We tested for changes in the composition, ecological associations, and diversity of ants (Hymenoptera: Formicidae) along a gradient of intensification of coffee production in the Colombian Andes. We surveyed 16 farms in two regions, classified into four management types: (1) forest (no agriculture), (2) organic polygeneric shaded coffee, (3) monogeneric shaded coffee, and (4) sun coffee (unshaded). Forty sampling units (20 1- $\mathrm{m}^{2}$ plots on the ground and 20 coffee bushes) were established at each farm between 2001 and 2002. We sampled with a mini-winkler litter extraction technique and through visual searching. Organic polygeneric shaded-coffee plantations contained significantly higher ant species richness, and their ant assemblages resembled the forest patches more than any other management type. The number of statistically significant associations among ant species dropped with production intensification, as did the number of ant species involved in such associations. The network of ant associations in shaded systems transformed into an extremely simplified network in sun coffee, with a few dominant ants extending almost entirely throughout the crop. Intensification of coffee agriculture not only caused loss of litter ant species (especially forest species) but also a reduction in the complexity of the ant assemblage in the leaf litter of this agroecosystem.
\end{abstract}

Key Words: agricultural intensification, ant associations, biodiversity loss, leaf-litter ants, shaded coffee

Reducción en la Diversidad y Complejidad del Ensamble de Hormigas de la Hojarasca en Plantaciones de Café Colombianas

Resumen: Recientemente, los agroecosistemas cafetaleros en Colombia, un país megadiverso, han experimentado una dramática intensificación, relacionada principalmente con la naturaleza de la cobertura de sombra. Buscamos cambios en la composición, asociaciones ecologicas y diversidad de bormigas (Hymenoptera: Formicidae) a lo largo de un gradiente de intensificación de la producción cafetalera en los Andes Colombianos. Muestreamos 16 fincas en dos regiones, clasificadas en cuatro tipos de manejos: (1) bosque (sin agricultura), (2) café orgánico con sombra poligenérica, (3) café con sombra monogenérica y (4) café de sol (sin sombra). Entre 2001 y 2002 se establecieron cuarenta unidades de muestreo (20, parcelas de 1 $m^{2}$ sobre el suelo y 20 plantas de café) en cada finca. Muestreamos con la técnica mini-winkler de extracción de bojarasca y con búsqueda visual. Las plantaciones de café orgánico con sombra poligenérica tuvieron una riqueza de especies de bormigas significativamente mayor, y sus ensambles fueron más semejantes a los de parches de bosque, que a cualquier otro tipo de plantación. El número de asociaciones estadísticamente significativas entre bormigas disminuyó con la intensificación de la producción, como también el número de especies de hormigas involucradas en tales asociaciones. La red de asociaciones de bormigas en sistemas con sombra se transformó en una red extremadamente simplificada en el café de sol, con unas cuantas bormigas dominantes en toda la plantación. La intensificación de la agricultura del café no solo provocó pérdida de 
especies de hormigas de la hojarasca (especialmente especies de bosque) sino también una reducción en la complejidad del ensamble de hormigas en la bojarasca de este agroecosistema.

Palabras Clave: asociaciones de hormigas, café de sombra, hormigas de la hojarasca, intensificación agrícola, pérdida de biodiversidad

\section{Introduction}

Extensive research has focused on tropical multistrata agroforestry systems, especially shaded coffee and cacao because of their potential to preserve associated biodiversity (Perfecto et al. 1996; Greenberg et al. 1997; Vandermeer \& Perfecto 1997) and because they can be used as templates for sustainable agricultural production systems (Somarriba et al. 2001). The coffee agroecosystem exists along an intensification gradient, in which rustic forest-like traditional agroforests (grown under a canopy of native forest trees) represent the most biodiverse extreme (Perfecto et al. 1996). Shade trees ameliorate adverse climatic conditions, nutritional imbalances, and extreme temperatures (Beer et al. 1998); provide producers with additional income sources (Greenberg \& Rice 2000); and potentially affect economic elasticities for small farmers and rural communities (Rice \& Ward 1996). Shaded systems have been increasingly transformed, however, to coffee plantations that have little or no shade (i.e., sun coffee) and high agrochemical inputs (fertilizers, insecticides, herbicides). Most studies show that the intensification of coffee results in a loss of associated biodiversity (e.g., Borrero 1986; Gallina et al. 1996; Greenberg et al. 1997; Perfecto et al. 1997; Moguel \& Toledo 1999; Rojas et al. 2001; Klein et al. 2002; Dietsch 2003). Although many farmers and extension agents cite yield increases to justify intensification of coffee farms, available data suggest that maximum yield may occur between 40-50\% (Soto-Pinto et al. 2000) or even up to $65 \%$ shade cover (Staver et al. 2001).

Although there is substantial evidence indicating the high potential of diverse agroecosystems to maintain biodiversity, a controversy about shade-grown coffee has recently emerged, motivated by two main concerns. The first is that price premiums paid to shade-coffee growers may encourage farmers to clear tropical forest remnant understories, effectively converting forests to coffee plantations (Rappole et al. 2003). Arguments contradicting this point of view emphasize the biodiversity preserved in traditionally shaded coffee and the importance of incorporating forest reserves in landscape-level conservation plans (e.g., Philpott \& Dietsch 2003; Perfecto \& Armbrecht 2003). The second concern is that the proximity of forest fragments, and not the habitat quality of agroecosystems per se, determines the conservation value of any specific farm (e.g., Ricketts et al. 2001). Regarding ants, there is higher diversity closer to forests and shaded coffee plantations provide a high-quality matrix within which biodiversity is conserved (Perfecto \& Vandermeer 2002; Armbrecht \& Perfecto 2003). Furthermore, shaded coffee might qualify as "better habitat" for forest species moving between forest fragments, which has important implications for conservation policy because migration through the agricultural matrix could determine the longterm survival and metapopulation dynamics of species inhabiting forest fragments (Vandermeer \& Carvajal 2001; Perfecto \& Vandermeer 2002).

Colombia is the third largest coffee-producing country in the world (International Coffee Council 2001) and has the largest area in unshaded-coffee plantations in northern Latin America (Perfecto et al. 1996). Only about 13\% of the coffee area cultivated is shaded, according to a survey done in 1997 (M. Velez, personal communication). Furthermore, the impacts of the transformation from shade to sun coffee on associated biodiversity have been noted (e.g., Borrero 1986; Sadeghian 2000; Botero \& Baker 2002). Given the continued promotion of converting to sun coffee (Borrero 1986; I.A., personal observation) in this acknowledged megadiverse country (Mittermeier et al. 1998), it seems important to assess the conservation value of shaded coffee. Knowing that ants (Hymenoptera: Formicidae) are highly sensitive to habitat changes (Peck et al. 1998; Andersen et al. 2002) and that elsewhere their diversity decreases when shade coffee is transformed into sun coffee (e.g., Perfecto \& Snelling 1995; Perfecto et al. 2003), this group of organisms represents an obvious taxon for studies of biodiversity loss associated with the intensification of the coffee agroecosystem. Thus our objectives were to test whether ecologically managed coffee agroecosystems (organic and shaded) are better at preserving the associated ant fauna, especially species characteristic of forest patches, and whether the ant community loses complexity with the intensification of coffee production. We tested two main hypotheses in Colombian farms across an intensification gradient of coffee production: (1) ant species richness is negatively affected by intensification of agriculture and (2) ant assemblages differ according to land management.

\section{Study Site}

We studied two regions in the Andes on the northwest side of Colombia near Apía (Apía Municipality, Department of Risaralda, $5^{\circ} 08^{\prime} \mathrm{N}, 75^{\circ} 56^{\prime} \mathrm{W}$ ) and Palermo, 


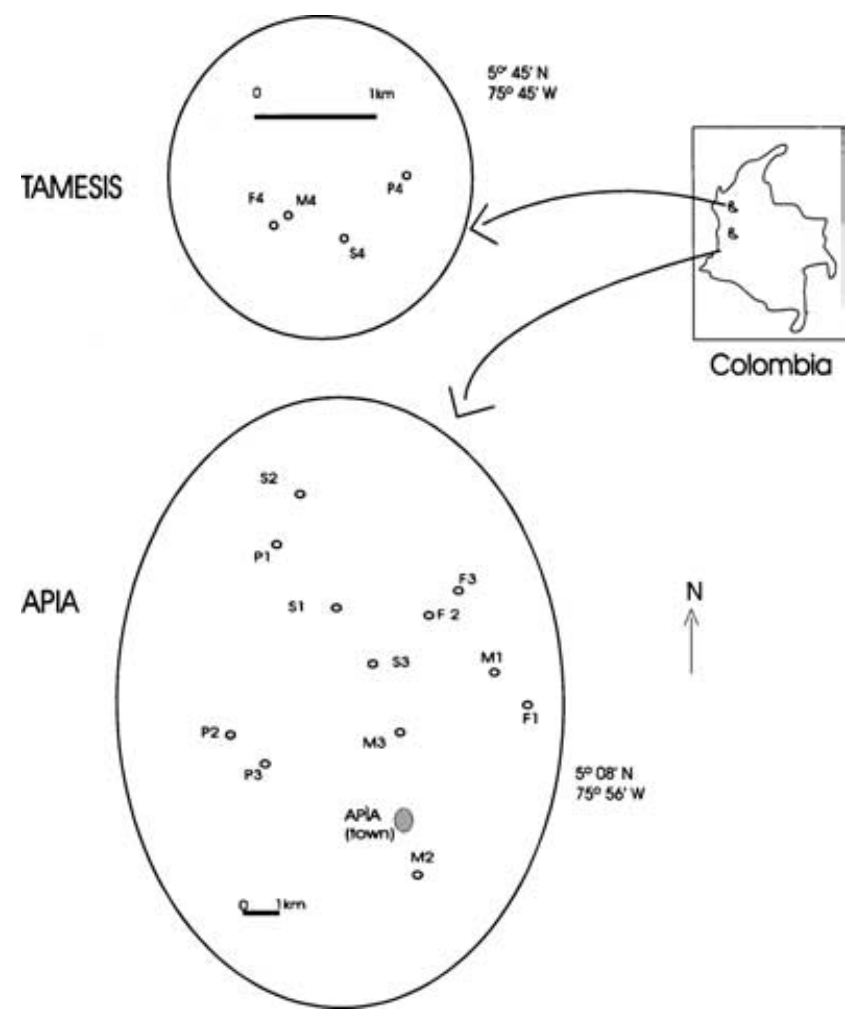

Figure 1. Location of the two study sites in Colombia and relative location of the farms within each study site. Twelve farms are located at Apía municipality (Risaralda Department) and four at Támesis municipality (Antioquia Department).

(Támesis Municipality, Antioquia Department, $5^{\circ} 45^{\prime} \mathrm{N}$, $75^{\circ} 45^{\prime} \mathrm{W}$ ) (Fig. 1). The average annual temperature is 20.0 $0^{\circ} \mathrm{C}$ and $19.3^{\circ} \mathrm{C}$ in Apía and Támesis, respectively. Annual precipitation is 2320 and $3300 \mathrm{~mm}$ (in Apía-Támesis, respectively), showing a bimodal distribution with two high rain peaks in May and November for Apía and in April-May and September-October for Támesis. Coffee is grown at both regions at elevations between approximately 1300-1750 $\mathrm{m}$ asl, usually on high slopes ( $40 \%$ average slope, I.A., unpublished data) irrigated by numerous creeks and situated among small, isolated forest fragments. Because of this topography and a recent accelerated process of intensification, the former landscape, dominated by forest-like shaded-coffee plantations, today looks like a mosaic of differently managed farms with an increasing trend toward sun-coffee farms and cattle pastures.

The Departments of Apía and Risaralda are among the most important coffee-producing regions of Colombia, together with Caldas, Quindío, and Valle. Most of the agricultural landscape in the region is sun coffee and increasingly cattle pasture (I. A., personal observations 20012003). Apía was one of the last places in which shaded coffee dominated the landscape before this study began.
In 2004, however, this situation was reversed, and the shaded plantations that we studied were already logged and transformed into sun coffee, except for the organic farms.

We selected 16 farms for study, 12 in Apía and 4 in Támesis (no more replicates were possible in Támesis for logistic reasons). We visited both municipalities in 2001 and located and interviewed farmers about their management. Based on results of the interviews, we made a preliminary classification of the farms and chose our study farms to represent a range of farms along the shadeto-sun intensification gradient. The farms in Apía were interspersed along an area of approximately $84 \mathrm{~km}^{2}(\sim 7$ $\times 12 \mathrm{~km})$, and farms in Támesis were separated from one another by no more than $400 \mathrm{~m}$ (Fig. 1). The coffee plantations studied were approximately 6 years old.

\section{Methods}

We classified the 16 farms into four management types (Nestel \& Altieri 1992) based on differences in the variety of the shade trees and amount of shade in order of increasing intensification: forest $(F)$, organic polygeneric shaded coffee $(\mathrm{P})$, monogeneric shaded coffee $(\mathrm{M})$, and coffee monoculture or sun coffee (S) (Table 1). Forests were small, isolated patches of secondary natural vegetation, not managed for any type of agriculture, with closed canopies about $15 \mathrm{~m}$ tall. Even though these forest patches were not coffee plantations, coffee bushes were occasionally found inside them among the natural understory. Using these secondary forests as representatives of the "forest" category suggests that we might expect less contrast, in terms of diversity, than if primary forests had been available. Polygeneric shadedcoffee farms contained shade trees belonging to different genera-approximately 10 species of trees per ha and all farms were under certified organic management, except P2 (La Esperanza, Table 1), in which agrochemical inputs were not used. Monogeneric shaded-coffee plantations were dominated ( $>80 \%$ of trees) by one species of tree (we did not consider Musa $\mathrm{x}$ paradisiaca $\mathrm{L}$. a shade tree). The sun-coffee plantations were mostly unshaded, although barriers of plantains (Musa $\mathrm{x}$ paradisiaca L.) were found around internal plots at each farm. Other isolated trees were also occasionally found in these suncoffee plantations. We measured habitat variables such as percent canopy cover, tree richness and density, number of logs, and number of twigs on the ground (data in Armbrecht 2003b).

\section{Ant Sampling in Leaf Litter}

To sample leaf-litter ants, 20 sampling units (SU) consisting of $1-\mathrm{m}^{2}$ plots were established on the ground following a transect, according to recommendations from the 
Table 1. Description of the 16 studied coffee farms in the Apía and Támesis municipalities of Colombia.

\begin{tabular}{|c|c|c|c|c|c|}
\hline Apía & F1 & Monteverde & 20 & 15 & 1845 \\
\hline Apía & $\mathrm{F} 3$ & El Porvenir & 19 & 1.5 & 1605 \\
\hline Támesis & $\mathrm{F} 4$ & La Cumbre & na & 0.7 & 1650 \\
\hline Apía & P1 & La Playita-1 & 6 & 15 & 1490 \\
\hline Támesis & $\mathrm{P} 4$ & El Paraíso de la Virgen & 12 & 25 & 1515 \\
\hline Apía & M1 & Monteverde & Cordia alliodora (R. et P.) Cham. & 4 & 1720 \\
\hline Apía & M2 & Buenos Aires & Inga edulis Mart. & 6 & 1440 \\
\hline Apía & M3 & El Convenio & Inga edulis Mart. & 4 & 1465 \\
\hline Támesis & M4 & La Cumbre & Cordia alliodora (R. et P.) Cham. & 6 & 1650 \\
\hline Apía & $\mathrm{S} 1$ & La Felisa & unshaded & 6 & 1480 \\
\hline
\end{tabular}

${ }^{a}$ Code: $F$, forest; $P$, organic polygeneric shaded coffee; $M$, monogeneric shaded coffee; and $S$, coffee monoculture or sun coffee.

${ }^{b}$ Abbreviation: na, not available (at least 10 species/ha).

leaf-litter ant protocol (Agosti \& Alonso 2000). The sampling units were $10 \mathrm{~m}$ apart. We carried out two leaf-litter sampling procedures (Bestelmeyer et al. 2000). The first procedure was hand collection and leaf-litter inspection. Before collecting the litter in the plot, we broke open all twigs and decayed logs to expose ant nests within them. We made an initial search to detect fast-moving ants, then followed up with 20 minutes of careful visual search and hand collection at each of the $1-\mathrm{m}^{2}$ plots (visual inspection was done before and after collecting the leaf litter). In the second procedure, we used the mini-winkler extraction method to sample ants not detected in the visual search. We scooped up all leaf litter inside the $1-\mathrm{m}^{2}$ plot from the edge of the quadrant toward the center and put it in the sifter sack, which we then shook laterally and vertically for 2-5 minutes, depending on the moisture of the litter. We placed the sifted litter in a sample bag and hung the sacks for 48 hours. We then extracted the ants in the laboratory with 20 mini-winkler extractors.

For both sampling methods we collected samples of ant workers, majors, queens, or males if present within colonies, and put them in vials with $70 \%$ ethanol. In the laboratory we separated them into morphospecies. Abundance of ants was determined as the number of individual workers (including majors but not reproductives) up to 99 . We considered counts over 99 very abundant and recorded the count as 100. Data from both sampling methods were combined to determine leaf-litter species richness and species accumulation curves in each management type.

\section{Ant Sampling on Coffee Bushes}

For each plot described above (litter), we labeled the nearest coffee bush and visually inspected it for ant pres- ence for 15 minutes. We recorded and took samples of any ant found on the coffee plant. Because forests seldom have coffee bushes, we sampled the nearest understory plant (regardless of its species) that was $1.5-3.0 \mathrm{~m}$ tall in the same way as described for coffee bushes. When ant activity was not easily observed, we shook the bush vigorously and then observed it for 1 minute. We also opened dry twigs on the bushes to look for ant nests and counted the number of ant workers. We recorded abundance of ants in the same way described previously for leaf-litter ants.

We identified all ants to genus based on keys from Bolton (1994) and Holldobler and Wilson (1990). Ant taxonomists determined specific names. Voucher specimens were deposited at the Museum of Entomology, Universidad del Valle, Cali, Colombia.

All farms at the Támesis municipality were sampled in September 2001. The Apía region was sampled twice: 12 farms once between 23 October and 4 November 2001 (wet season) and a second time between 20 January and 4 February 2002 (dry season). Sampling in different times of the year increases the possibility of finding more ant species than sampling only once, implying that the Támesis region could have had a higher richness than reported here.

\section{Data Analyses}

Because the observed number of species in a sampled community is a biased estimate of the real community species richness (Longino et al. 2002), we produced individual-based and sample-based rarefaction plots for each of the management types. Computations were carried out with the programs Ecosim (version 7; Gotelli \& Entsminger 2003), Past Program for Windows (Hammer 
et al. 2001; http://palaeoelectronica.org/2001_1/past/ issue1_01.htm), or Colwell's (1997) Estimate S-5. Because the number of sample units was the same across all treatments (management types), we directly compared observed richness from sample-based rarefaction curves (Longino \& Colwell 1997; Gotelli \& Colwell 2001) and after rarefaction to a common number of individual ants. To estimate the number of ant species at each of the two strata sampled (litter and coffee bushes), the nonparametric incidence-based coverage estimator (ICE) was obtained for each farm with the program Estimates (version 5; Colwell 1997). Details of its calculation are in Colwell's EstimateS (version 6). Nonparametric estimators will strongly correlate with the sample size until half of the total fauna is observed, but then they become gradually independent of sample size (Colwell \& Coddington 1994). The ICE values for each management type were then compared with a one-way analysis of variance (ANOVA; four management types, four farms in each) with SPSS-10 (SPSS, Chicago) Program for Windows.

We used resemblance functions (Ludwig \& Reynolds 1988 ) on the combined data from mini-winkler and hand collection to determine which coffee-management type preserves a higher number of species of forest leaflitter ants. We calculated Bray-Curtis percentage similarity index for the ant assemblages found in each of four polygeneric shaded-coffee plantations and their closest forests. We used the same procedure for the four monogeneric shaded-coffee plantations (M) and for the four sun-coffee farms in both regions. As a baseline reference, we also calculated the Bray-Curtis index for the ant assemblages between each possible pair of forest patches at Apía. We compared Bray-Curtis percent similarity values for the three coffee-management types with a KruskalWallis test for multiple samples.

The Bray-Curtis similarity index required choosing the lowest abundance of any two pairs of farms. Then, we divided twice the sum of such abundances values by the total of all the species abundances for the two farms. The Bray-Curtis index would reach $100 \%$ if any pair of farms had the same species with identical abundances. This sensitivity was the reason for choosing the index. Ant "abundance" was the number of sampling units at which the ant species $i$ was present. The 18 ant species (out of 115) present in all the coffee-management types were withdrawn from the analysis because they would not help discriminate similarity with forests and their large abundances would cause excessive noise in the index and undermine the presence of other, less-widespread species. Vertical stratification for the presence of ants was tested with a chi-square analysis.

To examine associations between ant species for each coffee-management type, we used chi-square analyses (Yates corrected because it is recommended for small sample sizes; Ludwig \& Reynolds 1988). Chi-square tests required checking the presence and absence of each possible pair of ant species in all the sampling units of the management type being analyzed. A matrix of those associations that were statistically significant was then constructed. If two ant species tended to occur together more frequently than by random chance, we considered the association positive. The number of associations was plotted against the categorical axis of four management types arranged in order of increasing intensification.

\section{Results}

We counted a total of 27,109 ants, 22,927 in Apía and 4,182 in Támesis. Sixty-nine percent of the ants came from leaf litter and 31\% from coffee bushes. In the Apía region there were 115 morphospecies, from which $42 \%$ and $6 \%$ were exclusive from leaf litter and coffee bushes, respectively. The remaining $52 \%$ of the ant species were found both in leaf litter and in coffee bushes. The Támesis region had 65 ant species, from which $46 \%$ and $18 \%$ were exclusive to leaf litter and coffee bushes, respectively. Seven of the nine subfamilies of Formicidae that exist in the Neotropics (Bolton 1994) were represented by ants collected in this study: Cerapachiinae, Dolichoderinae, Ecitoninae, Formicinae, Myrmicinae, Ponerinae, and Pseudomyrmecinae (a complete list of species is available from the authors or in Armbrecht 2003a).

\section{Ant Biodiversity and Intensification of Coffee Production}

The number of ant species per management type was highest in the polygeneric shaded-coffee plantations at both municipalities (Fig. 2). The average number of species in polygeneric shaded coffee was also higher in rarefaction curves based on either sampling units or number of individual ants (Table 2). Incidence-based coverage estimator mean values (Colwell 1997) for leaf-litter ants were statistically different $\left(F_{3,12}=3.99 ; p=0.035\right)$, and posthoc Tukey analyses revealed that the mean of polygeneric shaded-coffee farms was higher than that of sun coffee, $p=0.033$ ) but not different from the other shaded systems or the forests. Means of the ICE variable for coffee bushes were not statistically different for management types $(p=0.242)$.

The litter-ant fauna that most resembled forest patches was that from polygeneric shaded-coffee plantations (Fig. 3a), which also exclusively shared with forests the highest number of litter-ant species and individuals (Fig. $3 b)$. The average Bray-Curtis percentage similarity index among the forest patches in Apía was $25.49 \%( \pm 5.84$ SE). Bray-Curtis percent similarity indices were statistically different for the three coffee-management types involved in the study ( $H=8.346$; $\mathrm{df}=2 ; p=0.015$ ), and a posthoc analysis revealed that the means of the indices in polygeneric shaded-coffee plantations were significantly higher than those of sun-coffee plantations $(p=0.005)$. No differences were detected between any other possible combinations of management types 

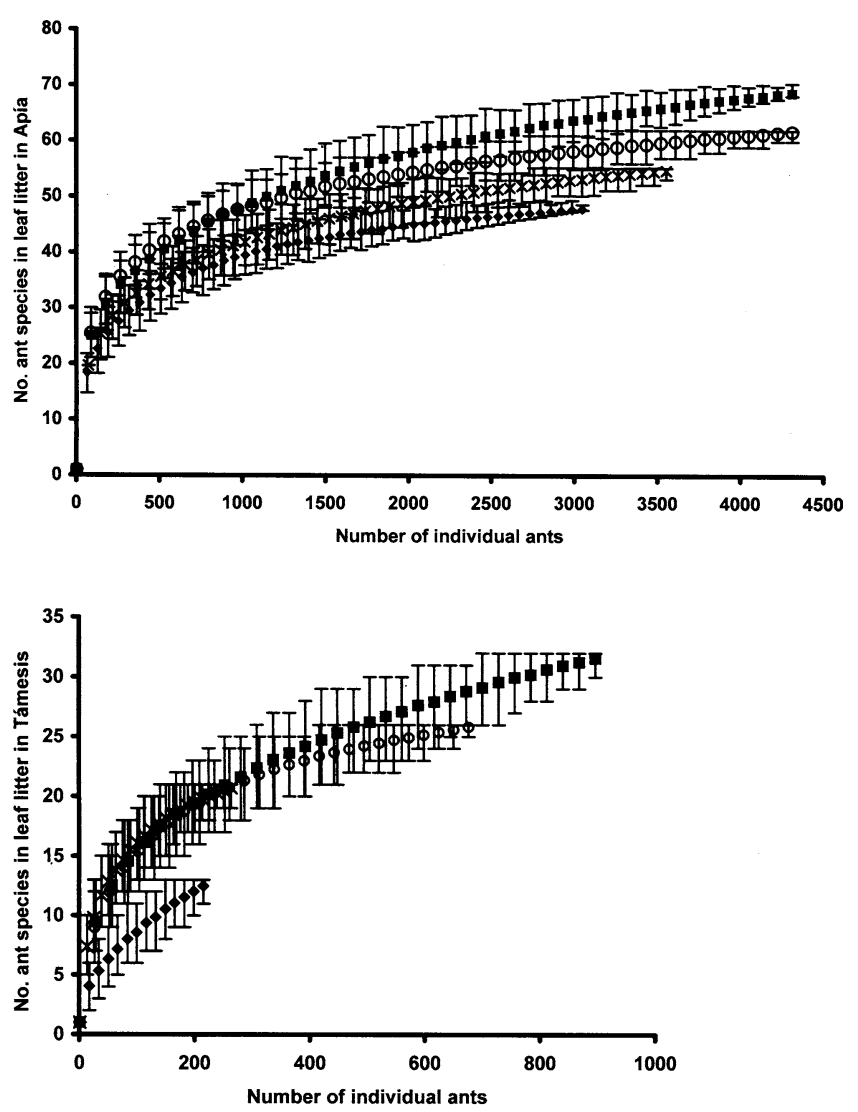

Figure 2. Individual-based rarefaction curves (Gotelli E Entsminger 2003) for ant species from litter samples in four management types along an intensification gradient of coffee production at Apía and Támesis municipalities. Open circles, forests; squares, polygeneric shaded-coffee plantations; Xs, monogeneric shaded-coffee plantations; diamonds, sun-coffee plantations. Vertical lines at each value are 95\% confidence limits.

(polygeneric shaded coffee versus monogeneric shaded coffee or monogeneric shaded coffee versus sun coffee; Fig. 3). No statistically significant differences were detected for the mean Bray-Curtis similarity indices for ants on coffee bushes, although a slight decreasing trend with intensification was noticeable. Forests harbored $20 \mathrm{ant}$ species and 681 individuals ( $n=4705$ total ants) not found elsewhere (32\% of its ant fauna), whereas 10 (30 individuals), 6 (101 individuals), and 5 (206 individuals) ant species were found exclusively in polygeneric shaded( $n=4656)$, monogeneric shaded- $(n=3731)$, and suncoffee plantations ( $n=3411)$, respectively.

\section{Ant Community in Leaf Litter and Coffee Bushes}

In general the identity of ant species assemblages in coffee bushes differed from that in leaf litter. Furthermore, the most abundant ant species, which were present in both strata, showed clear preferences either for coffee bushes or leaf litter compared with what would be expected in a null model. The hypothesis that the ant samples from coffee bushes come from a population having the same abundance distribution (in terms of number of sampling units present) as the sample of the ant species in leaf litter was rejected for both municipalities, Apía $\left(\chi^{2}=3809.6\right.$; df $=27 ; p=\ll 0.0001)$ and Támesis $\left(\chi^{2}=1243.9 ; \mathrm{df}\right.$ $=9 ; p=\ll 0.0001)$. Interestingly, ants that nest on the ground (soil, wood, or leaf-litter nesters) tended to forage on coffee bushes more than vice versa. Other important soil-nesting ants such as Solenopsis picea, Pyramica gundlachi, and Octostruma balzani were seldom or never found on coffee bushes. Conversely, species such as Procryptocerus scabriusculus, Linepithema mo., and $A z t e c a \mathrm{~cm}$. nested and preferred the upper levels on coffee bushes and were seldom found in leaf litter.

The most abundant ant species were differentially affected by production intensification. Some species declined in abundance along the intensification gradient, other species showed higher abundances at intermediate levels, and still others were abundant only within the forests or the sun-coffee system (detailed information in Armbrecht [2003a]).

\section{Loss of Ecological Associations with Intensification of Coffee Production}

From all possible pair-wise combinations of ant species, most of the significant associations occurred in the leaf litter and the Apía municipality (Figs. 4 \& 5). Overall, both the number of species involved and the associations decreased with intensification (Fig. 4). Three ant species played an important role in the sun-coffee plantations, and all of these were more abundant in coffee plantations than in forests: Gnamptogenys striatula (present in only one of the sun-coffee plantations), $P h$. radoszkowski, and $S$. picea.

The network of significant associations among ant species was more complex in shaded systems than in sun-coffee plantations (Fig. 5). Ants on the forest floor exhibited more variation in terms of the distribution and variety of ant species detected along the transects than in any of the coffee plantations examined. Only two significant associations were detected in the ant assemblages at Támesis municipality, both at the polygeneric shadedcoffee farm. No significant associations between any possible ant species were found at the coffee-bush level at Támesis.

The variety and distribution of leaf-litter ants became less complex, and abundant ants tended to be less restricted spatially (i.e., one ant species present in discrete small segments along the transects) as intensification of coffee production increased. Thus, specific species associated differently with other species as the management conditions changed (e.g., S. picea, Ph. radoszkowski; Fig. 5). At Támesis municipality Pbeidole gm. and Crematogaster ng. tended to decrease with intensification, whereas $S$. picea increased, showing a trend similar to that 
Table 2. Number of ant species in coffee plantations of Apía (farms 1-3) and Támesis (number 4).

\begin{tabular}{|c|c|c|c|c|}
\hline \multirow[b]{2}{*}{ Farm/management ${ }^{a}$} & \multicolumn{2}{|c|}{$\begin{array}{l}\text { Total number of species in } \\
20 \text { sampling units }\left(1-m^{2} \text { plots }\right)\end{array}$} & \multicolumn{2}{|c|}{$\begin{array}{c}\text { Number of species after rarefaction } \\
\text { to a common number of } \\
\text { individuals (from past program) }\end{array}$} \\
\hline & $\begin{array}{l}\text { leaf } \\
\text { litter }\end{array}$ & $\begin{array}{l}\text { coffee bushes or } \\
\text { understory plants }\end{array}$ & $\begin{array}{l}\text { leaf litter } \\
\mathrm{n}=710\end{array}$ & $\begin{array}{c}\text { coffee bushes } \\
\mathrm{n}=180\end{array}$ \\
\hline \multicolumn{5}{|l|}{ Forest } \\
\hline 1 & 33 & 15 & 30 & 15 \\
\hline 4 & 26 & 16 & 25 & 13 \\
\hline $\mathrm{All}^{b}$ & 32.3 & 15.0 & 28.5 & 13.3 \\
\hline \multicolumn{5}{|l|}{ Polygeneric shaded coffee } \\
\hline 1 & 38 & 17 & 32 & 11 \\
\hline 2 & 37 & 25 & 35 & 16 \\
\hline 3 & 43 & 25 & 31 & 16 \\
\hline 2 & 31 & 24 & 28 & 19 \\
\hline 3 & 28 & 17 & 24 & 11 \\
\hline 4 & 20 & 12 & 14 & 9 \\
\hline $\mathrm{All}^{b}$ & 26.0 & 17.5 & 22.3 & 13.3 \\
\hline \multicolumn{5}{|l|}{ Sun coffee } \\
\hline 1 & 28 & 18 & 25 & 14 \\
\hline 2 & 33 & 13 & 30 & 11 \\
\hline 3 & 23 & 17 & 23 & 13 \\
\hline 4 & 13 & 9 & 17 & $9^{c}$ \\
\hline $\mathrm{All}^{b}$ & 24.3 & 14.3 & 23.8 & 12.7 \\
\hline Kruskal-Wallis $\mathrm{H}$ and $p(\mathrm{df}=3)$ & $\mathrm{H}=8.43, p=0.038$ & $\mathrm{H}=6.76, p=0.08^{d}$ & $\mathrm{H}=8.63, p=0.035$ & $\mathrm{H}=1.68, p=0.64$ \\
\hline
\end{tabular}

${ }^{a}$ Farm and management type defined in Table 1 and ordered in an increasing intensification gradient.

${ }^{b}$ Averages for each management type (preceding 4 rows).

${ }^{c}$ Not available. In $S 4$ rarefaction went up to only 100 individuals; therefore, this number (9) was not counted for average or statistics.

${ }^{d}$ Not significant.

of $S$. picea in Apía. This last ant species was the secondmost abundant in Apía and Támesis.

\section{Discussion}

Our results demonstrate that loss of ant biodiversity in the leaf litter with intensification of agriculture occurs not only in terms of specific species identities but also in terms of ecological associations and complexity. Organic polygeneric shaded-coffee plantations harbored more species of litter ants and resembled forest patches significantly more than either monogeneric shaded- or sun-coffee plantations.

Forests had a higher number of exclusive ant species and ant individuals. These patches of natural vegetation had probably always represented a habitat more diverse in topography, vegetation structure, and possibly in species composition, even before the coffee farms were created. Consequently, in conservation terms, forests cannot be replaced by any of the agroecosystems.

Our results suggest that ants on coffee bushes are not as negatively influenced by coffee production intensifica- tion as are ants of the litter stratum, which is consistent with other studies (Perfecto \& Snelling 1995), possibly because ants on the coffee bushes of these plantations tend to be present in both soil and bushes (only 6\% were exclusive to coffee bushes). An alternative explanation is that most ant species that are vulnerable to shade elimination are eliminated in the very first stages of intensification (e.g., transformation from rustic coffee to polygeneric shaded coffee); therefore, we did not detect these species.

Additionally, both Apía and Támesis revealed that ant species differed their identities at the leaf-litter and coffeebush strata $(p<0.0001)$. Therefore, for agroecological purposes, both these strata must be taken into account when devising management practices. For example, after establishing that an ant species is an efficient predator of some coffee herbivores under laboratory conditions and that this species is also a dominant ant (e.g., S. picea), it makes no sense to promote it for purposes of biological control if no foraging occurs on coffee bushes where the herbivore is found.

In terms of biodiversity loss of leaf-litter ants specifically related to intensification, our study is new for Colombia 

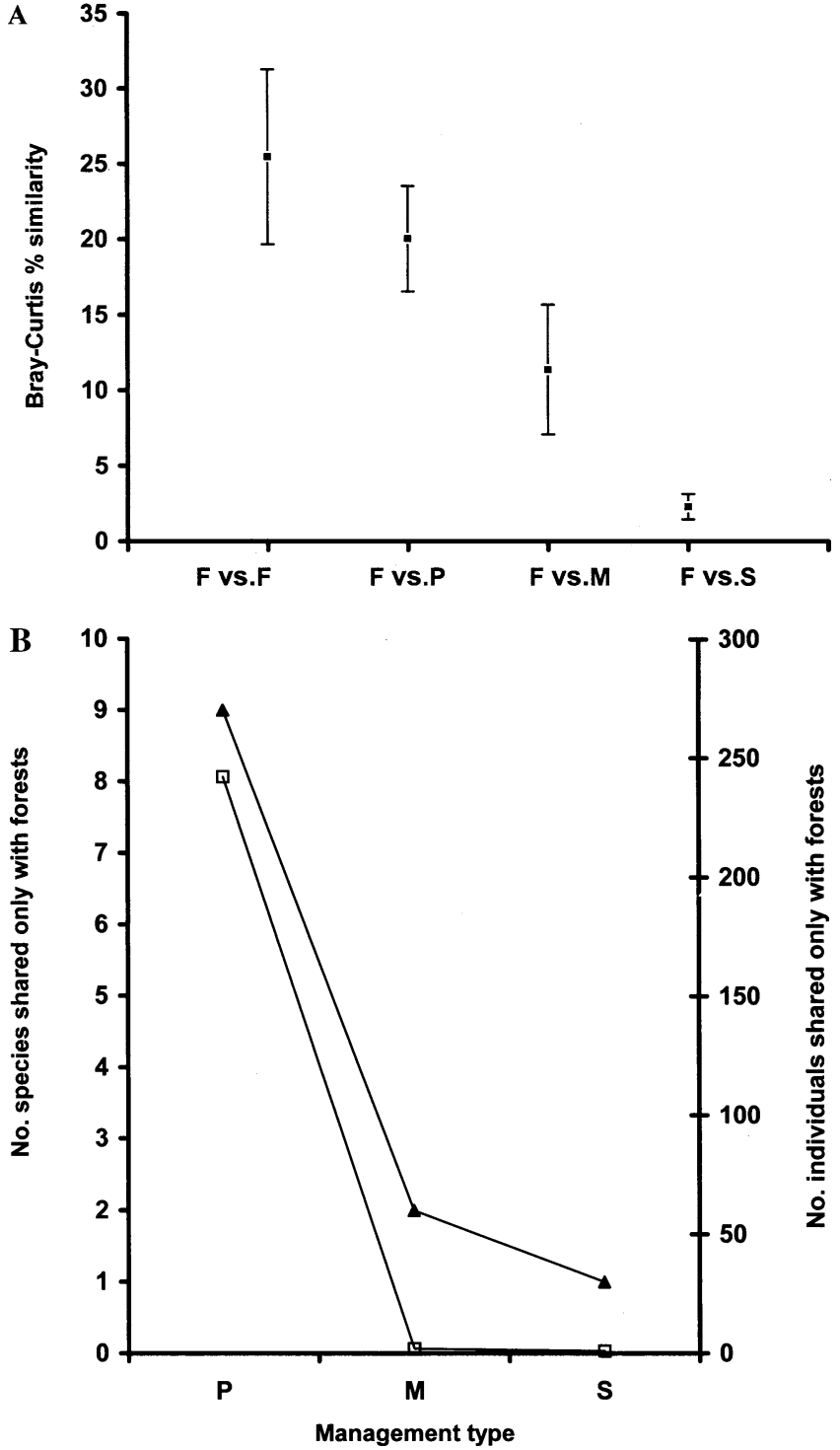

Figure 3. (a) Mean \pm SE Bray-Curtis percent similarity index for leaf-litter ants $(\mathrm{n}=4)$ for each coffee-management type versus forest patches. For reference, forest versus forest mean is shown at the left side of the plot (only at the Apia municipality and not included in the statistical analysis). (b) Number of litter ant species (black triangles) and individuals (open squares) that are exclusively shared by forests versus each coffee-management type at Apía ( $P$, polygeneric shaded coffee; $M$, monogeneric shaded coffee; $S$, sun coffee).

(but see Sadeghian 2000; Sossa \& Fernández 2000) and consistent with other studies of ants in coffee plantations (Perfecto \& Snelling 1995; Perfecto \& Vandermeer 2002; Armbrecht \& Perfecto 2003). Lack of pesticide or agrochemical use may be an important factor influencing the high conservation potential of the polygeneric shaded coffee and forests versus monogeneric shaded and sun

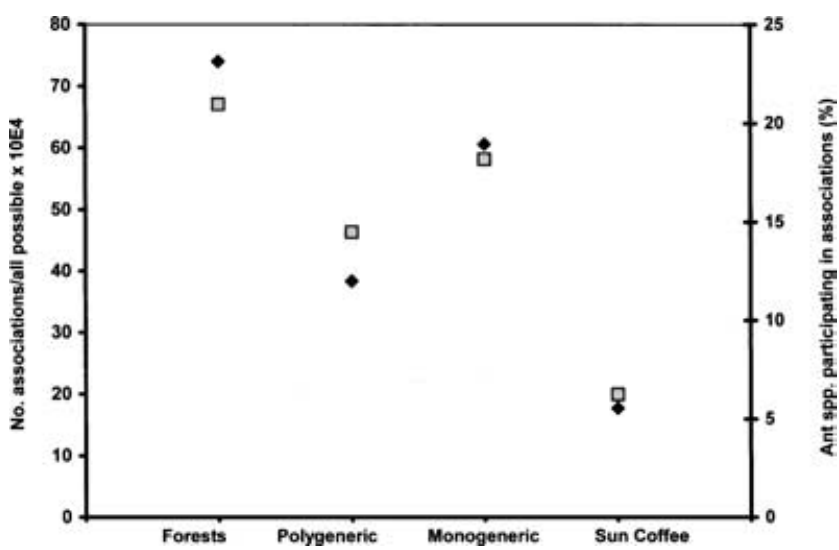

Figure 4. Simplification of the system and loss in the diversity of associations in the leaf litter level in Apía municipality: squares, percentage of ant species (relative to each management type) involved in significant associations with other ant species; diamonds, significant ant associations relative to all possible ant associations that could have possibly occurred in each management type. The categorical abscissa is ordered along an increasing gradient of intensification of coffee production.

coffee. We could not, however, separate this "agrochemical input" factor from others that are also associated with higher intensification and thus cannot provide direct evidence that this is a causal factor.

Significantly higher Bray-Curtis similarity indices and higher numbers of exclusively shared ant species (Fig. 3) showed that organic polygeneric shaded-coffee preserves forest-litter ant fauna significantly more than any other coffee type. Polygeneric shaded coffee was a better habitat for forest ants regardless of the distance from forest patches to the coffee plantations. Furthermore, forests at Apía were frequently separated more from polygeneric shaded coffee than from sun coffee (Fig. 1). Forest- 4 and the monogeneric shaded- 4 coffee farm at Támesis were neighbors. These results contradict findings in a study of moth diversity in Costa Rica (Ricketts et al. 2001) in which the most important factor determining biodiversity of this taxon was the distance to the forest (one large reserve), regardless of the habitat quality within agricultural matrix. Data from another study in Mexico showed that more fruit-feeding butterflies were shared by rustic coffee plantations and forest fragments than intensively managed shaded coffee plantations (Mas 1999), which is consistent with our results. Recall that 18 very abundant ant species (those present in all systems) were withdrawn from our Bray-Curtis computations (see data analyses).

Previous studies comparing arthropod species richness between forest and shaded-coffee plantations (including rustic ones) have shown forests with higher or similar species richness (see review in Perfecto \& Armbrecht 


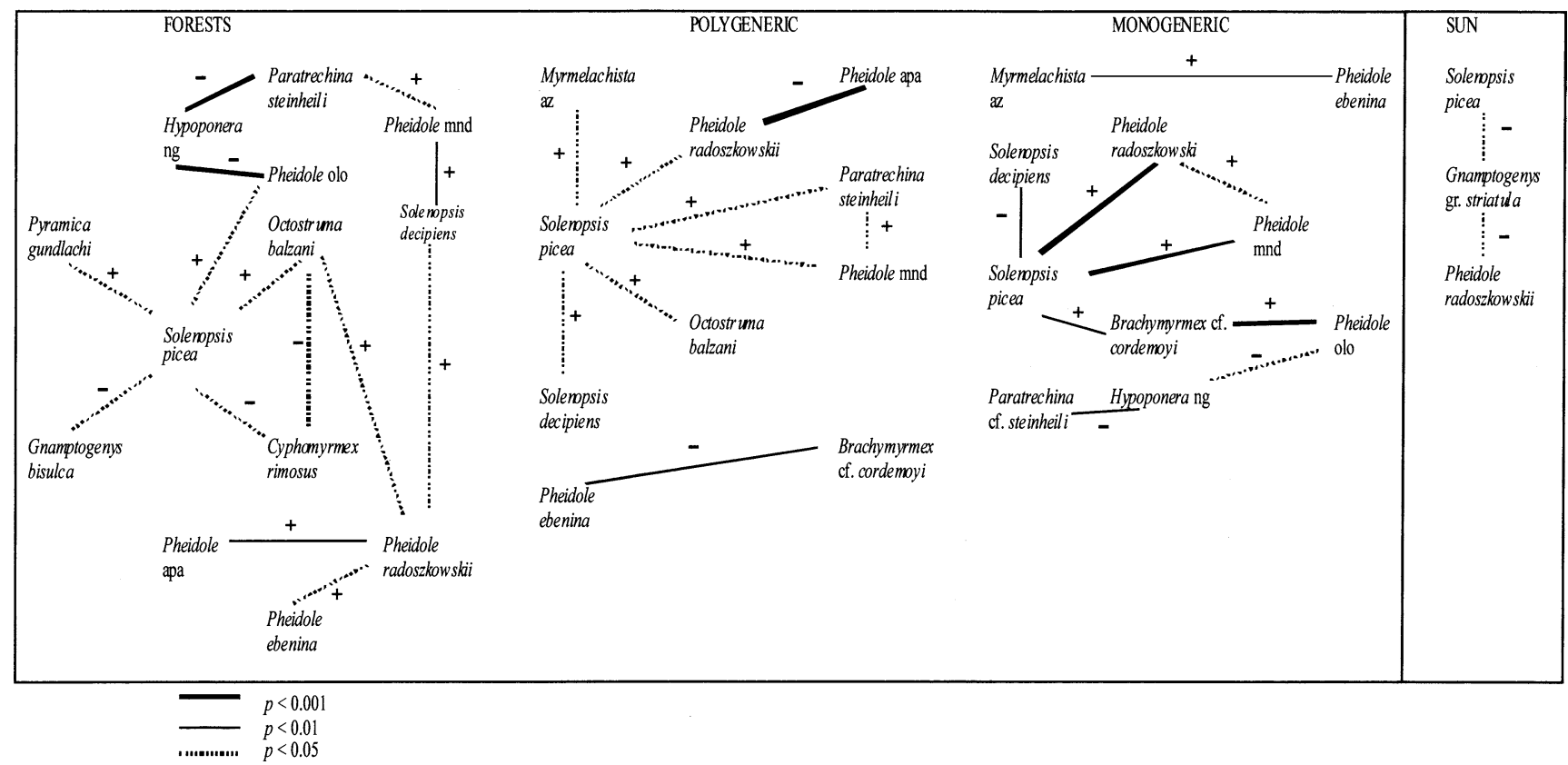

Figure 5. Network of statistically significant associations among leaf-litter ants at Apia in forests and three coffeemanagement types. Lines labeled (+) or (-) were positive or negative associations, respectively. Lines connecting ant species become thicker with increasing chi-square test significance (footnote lowest part of figure).

2003). The question of why forests in our study were not richer than polygeneric shaded-coffee plantations was possibly answered by the fact that these forests were secondary and small. The forests we studied were very disturbed and could have already lost many of their ant species. Also, some sensitive rare ant populations were possibly at such low densities that we could not detect them. An alternative explanation is that because polygeneric shaded-coffee plantations are more open than forests (lower percent canopy cover, Armbrecht 2003b), they more resemble natural vegetation at lower elevations. Therefore ant species might migrate from lower elevations without excluding ants at the higher elevation, resulting in higher species richness.

The number of ant species involved in associations and the number of associations between any pair of ant species decreased with intensification of coffee production (Fig. 5), leading to a system in which only a few ant species, with high populations, dominate. Possibly, in sun-coffee plantations, few ants (e.g., S. picea) were able to competitively exclude other ants with increasing intensification (e.g., Cyphomyrmex rimosus; Fig. 4). Some of these ant species appeared to be severely decimated at the very first stage of agricultural transformation (i.e., from forest to shaded coffee) (e.g., Hypoponera ng, Gnamptogenys bisulca, Cyphomyrmex rimosus, Rogeria ne), and some of these species associated negatively (i.e., seemed to exclude each other) with other ant species that became numerically and spatially important in the sun-coffee system (e.g., S. picea, Ph. radoszkowski; Fig. 5). As spatial variability decreased with intensifica- tion, the system was "taken over" by ants favored by the changing conditions, in this case $P h$. radoszkowski, $S$. picea, and Gnamptogenys striatula, all of which nest in soil. Other ant species, such as Tetramorium simillimum, G. striatula, and Wasmannia auropunctata, became important only under the most intensified conditions of sun-3 (La María farm, which is the only farm that had been unshaded for 12 years, the other sun-coffee farms having been converted from shade within 2 years before the study).

Forests had twice as many exclusive ant species as polygeneric shaded and three to four times more than the other two management types. These numbers suggest that even though forest patches may contain fewer ant species than the polygeneric shaded coffee (Fig. 2), they maintain more unique ant species. This means that preserving these forest fragments within the agroecological matrix should be an integrated part of the landscape conservation program (i.e., controversy in Rappole et al. 2003). Additionally, our results suggest that the quality of the matrix (regardless of the proximity to forests, at the spatial scale of our study) plays a key role in preserving a higher diversity of the litter-ant fauna. Sun coffee and monogeneric shaded coffee were closer to the forests both in Apía and Támesis (Fig. 1), but in both regions polygeneric shaded coffee's ant fauna was richer than any other system.

Ultimately there are three main components that determine the importance of agriculture for the conservation of biodiversity (Perfecto 2003): the matrix that surrounds protected areas, agroecosystems per se as habitats 
for wildlife, and human productive activities inside and outside protected areas. Our results have important implications in terms of the second component (the forests studied are not protected) and we recommend promoting organic and (or) diversified shaded coffee as a priority in the Andean coffee-growing region in addition to protecting the forested areas. Diversified coffee agroecosystems may have economic advantages from timber, coffee, and other nontimber products (Beer et al. 1998). Coffee biodiversity may also be preserved by making linkages between conservation-oriented agriculture and social justice (e.g., by means of directly paying farmers more for growing coffee crops in farms managed for biodiversity preservation) (Philpott \& Dietsch 2003).

\section{Conclusions}

Intensification of agriculture results in a loss of diversity of species associations and therefore affects species interactions, complexity, and variability within the communities of the coffee agroecosystem in Colombia. Our first hypothesis that ant richness is affected by intensification was confirmed and the less-intensified coffee system (organic polygeneric shaded coffee) was the richest habitat in the study.

Our second hypothesis that ant assemblages differ according to coffee land management was also confirmed. The loss of ant species and their associations in sun coffee especially affected ant species most characteristic of the forest habitat. Organic polygeneric shaded-coffee plantations were more similar to forests than monogeneric shaded-coffee or sun-coffee plantations. Additionally, the network of community associations and spatial variability became less complex with agricultural intensification. Conservation goals were better met within the concept of organic management in the polygeneric shaded farms.

\section{Acknowledgments}

We are grateful to G. Alvarez Saa, E. Jiménez, M. C. Gallego Ropero, and G. Vargas for field and laboratory work. Thanks to farmers at Apía and Támesis for allowing us to work in their plantations. Logistic support was provided by O. Díaz, F. Herrera, N. Henao (Orgánica Tatamá at Apía), C. M. Correa, J. M. Correa, J. Botero, M. Vélez Hoyos, P. Marín, and E. Mayes. Ant species were determined by T. Arias, F. Fernández, C. Kugler, J. Lattke, J. Longino, J. Pacheco, J. Trager, and P. Ward. B. Rathcke, E. Silverman, J. Vandermeer, an assigning editor, E. Main, and two unknown reviewers improved earlier versions of this manuscript. This project was financed by the International Institute University of Michigan, the Universidad del Valle, and Colciencias project grant code 110612-11693.

\section{Literature Cited}

Agosti, D., and L. E. Alonso. 2000. The ALL Protocol, a standard protocol for the collection of ground-dwelling ants. Pages 204-206 in D. Agosti, J. D. Majer, L. E. Alonso, and T. R. Shultz, editors. Ants: standard methods for measuring and monitoring Biodiversity. Smithsonian Institution, Washington, D. C.

Andersen, A. N., B. D. Hoffmann, W. J. Muller, and A. D. Griffiths. 2002. Using ants as bioindicator in land management: simplifying assessment of ant community responses. Journal of Applied Ecology 39: 8-17.

Armbrecht, I. 2003a. Diversity and function of leaf litter ants in Colombian coffee agroecosystems. Ph.D. dissertation. School of Natural Resources and Environment, University of Michigan, Ann Arbor.

Armbrecht, I. 2003b. Habitat changes in Colombian coffee farms under increasing management intensification. Endangered Species Update 20:163-178.

Armbrecht, I., and I. Perfecto. 2003. Litter-twig dwelling ant species richness and predation potential within a forest fragment and neighboring coffee plantations of contrasting habitat quality in Mexico. Agriculture, Ecosystems and Environment 97:107-115.

Beer, J., R. Muscheler, D. Kass, and E. Somarriba. 1998. Shade management in coffee and cacao plantations. Agroforestry Systems 38:139164.

Bestelmeyer, B. T., D. Agosti, L. E. Alonso, C. R. F. Brandao, W. L. Brown Jr., J. H. C. Delabie, and R. Silvestre. 2000. Field techniques for the study of ground-dwelling ants. Pages 122-144 in D. Agosti, J. D. Majer, L. E. Alonso, and T. R. Shultz, editors. Ants: standard methods for measuring and monitoring Biodiversity. Smithsonian Institution, Washington, D.C.

Bolton, B. 1994. Identification guide to the ant genera of the world. Harvard University Press, Cambridge, Massachusetts.

Borrero, J. I. 1986. La substitución de cafetales de sombrío por caturrales y su efecto negativo sobre la fauna de vertebrados. Caldasia 15:725732 (in Spanish).

Botero, J. E., and P. S. Baker. 2002. Coffee and biodiversity: a producercountry perspective. Coffee Futures, Chinchiná, Colombia.

Colwell, R. K. 1997. User's guide to Estimates 5. Statistical estimation of species richness and shared species from samples. Available from http://viceroy.eeb.uconn.edu/estimates (accessed May 2004).

Colwell, R. K., and J. A. Coddington. 1994. Estimating terrestrial biodiversity through extrapolation. Chapter 10. Philosophical Transactions of the Royal Society of London, Series B 345:101-118.

Dietsch, T. V. 2003. Conservation and ecology of birds in coffee agroecosystems of Chiapas, Mexico. Ph.D. dissertation. School of Natural Resources and Environment, University of Michigan, Ann Arbor.

Gallina, S., S. Mandujano, and A. González-Romero. 1996. Conservation of mammalian biodiversity in coffee plantations of Central Veracruz, Mexico. Agroforestry Systems 33:13-27.

Gotelli, N. J., and R. K. Colwell. 2001. Quantifying biodiversity: procedures and pitfalls in the measurement and comparison of species richness. Ecology Letters 4:379-391.

Gotelli, N. J., and G. L. Entsminger. 2003. EcoSim: null models software for ecology. Version 7. Acquired Intelligence and Kesey-Bear, Burlington, Vermont. Available from http://homepages.together. net/ gentsmin/ecosim.htm (accessed April 2003)

Greenberg, R., and R. A. Rice. 2000. The Peruvian shade-grown coffee primer migratory bird center, Smithsonian Institution, Washington, D.C.

Greenberg, R., P. Bichier, A. Cruz Angon, and R. Reitsma. 1997. Bird populations in shades and sun coffee plantations in central Guatemala. Conservation Biology 11:448-459.

International Coffee Council (ICC). 2001. Examen de la situación del mercado cafetero. 84 periodo de sesiones ICC 84-3. ICC, London (in Spanish).

Hammer Ø., D. Harper, and P. Ryan. 2001. Past: paleontological statistics 
software package for education and data analysis. Palaeontologia Electronica 4:1-9

Holldobler, B., and E. O. Wilson. 1990. The ants. Springer-Verlag, Berlin. Klein, A. M., I. Steffan-Dewenter, D. Buchori, and T. Tscharntke. 2002. Effects of land-use intensity in tropical agroforestry systems on coffee flower-visiting and trap-nesting bees and wasps. Conservation Biology 16:1003-1014.

Longino, J. T., and R. K. Colwell. 1997. Biodiversity assessment using structures inventory: capturing the ant fauna of a tropical rain forest. Ecological Applications 7:1263-1278.

Longino, J. T., J. Coddington, and R. K. Colwell. 2002. The ant fauna of a tropical rain forest: estimating species richness three different ways. Ecology 83:689-702.

Ludwig, J. A., and J. Reynolds. 1988. Statistical ecology: a primer on methods and computing. Wiley, New York.

Mas, A. H. 1999. Butterflies as biodiversity indicators and shade coffee certification in Chiapas, Mexico. M.S. thesis. School of Natural Resources and Environment, University of Michigan, Ann Arbor.

Mittermeier, R., N. Mayers, J. B. Thomsen, G. A. B. da Fonseca, and S. Olivieri. 1998. Biodiversity hotspots and major tropical wilderness areas: approaches to setting conservation priorities. Conservation Biology 12:516-520.

Moguel, P., and V. M. Toledo. 1999. Biodiversity conservation in traditional coffee systems of Mexico. Conservation Biology 13:11-21.

Nestel, D., and M. A. Altieri. 1992. The weed community of Mexican coffee agroecosystems: effect of management upon plant biomass and species composition. Acta Ecologica 13:715-726.

Peck, S. L., et al. 1998. Using ant species (Hymenoptera: Formicidae) as a biological indicator of agroecosystem condition. Environmental Entomology 27:1102-1110.

Perfecto, I. 2003. Conservation biology and agroecology: de un pájaro las dos alas. Endangered Species Update 20:133-145.

Perfecto, I., and I. Armbrecht. 2003. Technological change and biodiversity in the coffee agroecosystem of northern Latin America. Pages 159-194 in J. Vandermeer, editor. Tropical agroecosystems. CRC Press, Boca Raton, Florida.

Perfecto, I., and R. Snelling. 1995. Biodiversity and the transformation of a tropical agroecosystem: ants in coffee plantations. Ecological Applications 5:1084-1097.

Perfecto, I., and J. Vandermeer. 2002. The quality of agroecological matrix in a tropical montane landscape: ants in coffee plantations in southern Mexico. Conservation Biology 16:174-182.

Perfecto, I., A. Mas, T. Dietsch, and J. Vandermeer. 2003. Conservation of biodiversity in coffee agroecosystems: a tri-taxa comparison in southern Mexico. Biodiversity and Conservation 12:12391252.
Perfecto, I., R. A. Rice, R. Greenberg, and M. E. Van der Voort. 1996. Shade coffee: a disappearing refuge for biodiversity. Bioscience 46:598-608.

Perfecto, I., J. Vandermeer, P. Hanson, and V. Cartin. 1997. Arthropod diversity loss and the transformation of a tropical agroecosystem. Biodiversity and Conservation 6:935-945.

Philpott, S. M., and T. Dietsch. 2003. Coffee and conservation: a global context and the value of farmer involvement. Conservation Biology 17:1844-1846.

Rappole, J. H., D. I. King, and J. H. Vega-Rivera. 2003. Coffee and conservation. Conservation Biology 17:334-336.

Rice, R. A., and J. R. Ward. 1996. El café, la conservación ambiental y el comercio en el hemisferio occidental. Centro de Aves Migratorias Smithsonian Institution (SMBC), Consejo para la Defensa de los Recursos Naturales (NRDC), Washington, D.C. (in Spanish).

Ricketts, T. H., G. C. Daily, P. R. Ehrlich, and J. P. Fay. 2001. Countryside biogeography of moths in a fragmented landscape: biodiversity in native and agricultural habitats. Conservation Biology 15:378-388.

Rojas, L., C. Godoy, P. Hanson, C. Kleinn, and L. Hilje. 2001. A survey of homopteran species (Auchenorrhyncha) from coffee shrubs and poro and laurel trees in shaded coffee plantations, in Turrialba, Costa Rica. Revista de Biologia Tropical 49:1057-1065.

Sadeghian, S. 2000. Diversidad de mesoorganismos del suelo en la zona cafetera. Page 20 in Federación nacional de cafeteros de Colombia, editors. Memorias Foro Internacional Café y Biodiversidad, Chinchiná, Colombia (in Spanish).

Somarriba, E., J. Beer, and R. G. Muschler. 2001. Research methods for multistrata agroforestry systems with coffee and cacao: recommendations from two decades of research at CATIE. Agroforestry Systems 53:195-203.

Sossa, J., and F. Fernandez. 2000. Himenopteros de la franja cafetera del departamento del Quindío. Pages 168-180 in C. Numa and L. P. Romero, editors. Biodiversidad y sistemas de producción cafetera en el Departamento del Quindío. Instituto Alexander von Humboldt, Bogotá, Colombia (in Spanish).

Soto-Pinto, L., I. Perfecto, J. Castillo-Hernandez, and J. Caballero-Nieto. 2000. Shade effect on coffee production at the northern Tzeltal zone of the state of Chiapas, Mexico. Agriculture, Ecosystems and Environment 80:61-69.

Staver, C., F. Guharay, D. Monterroso, and R. G. Muschler. 2001. Designing pest suppressive multistrata perennial crop systems: shade grown coffee in Central America. Agroforestry Systems 53:151-170.

Vandermeer, J., and I. Perfecto. 1997. The Agroecosystem: a need for the conservation biologist's lens. Conservation Biology 11:591-592.

Vandermeer, J., and R. Carvajal. 2001. Metapopulation dynamics and the quality of the matrix. The American Naturalist 159:211-220.

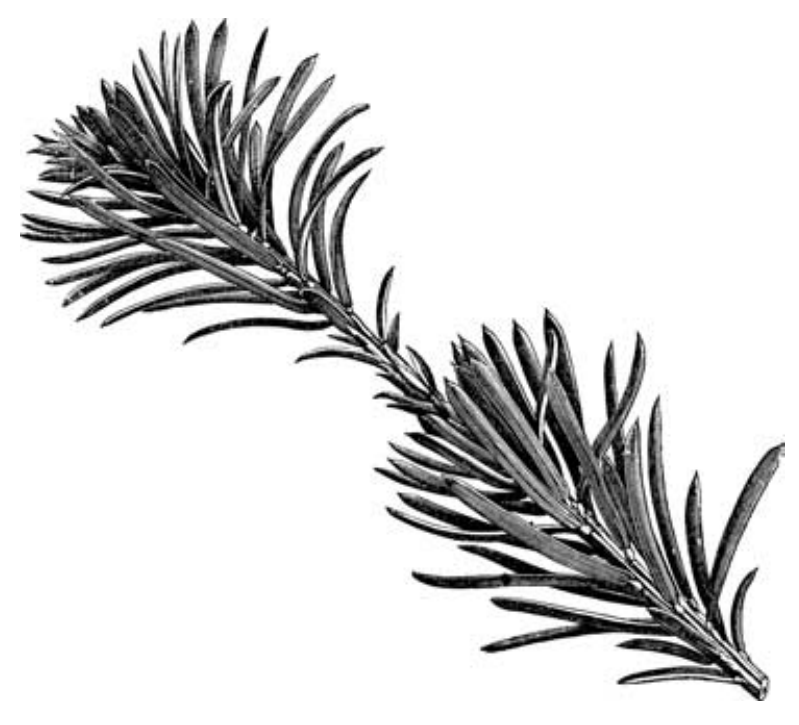

